\title{
The African Continental Free Trade Agreement: Why Should the Republic of Benin Ratify the Agreement? Three Possible Explanations
}

\author{
Ousmane Amadou \\ Eastern Mediterranean University, Faculty of Business and Economics, department of International Relations (North Cyprus)
}

\begin{abstract}
Every economic decision is motivated by mostly "Tree Big Ideas": incentives, the power of trade, and the institutional framework. The motives behind the creation of the African Continental Free Trade Area (AfCFTA) combine some of these ideas; they were inspired by the neoliberal free trade theory. From the conception to the implementation of the first phase of negotiations, many scholars and international institutions in Africa and around the world evaluated and analyzed the potential social, economic, and political impacts of the agreement. Some evaluations seem optimistic while others are cautious. But most of them failed to appreciate how individual countries' perspectives can also impact in the implementation process. States are sovereign entities and as such are free to choose whether or not to participate in free trade agreements. No scholarly article so far tried to analyze why Republic of Benin should to ratify the AfCFTA and its impacts on the economy of the country. Certainly, the Republic of Benin and several other states that, are yet to ratify the agreement are still carefully analyzing the possible outcomes. This research aims to apply Cowan \& Tabarrok (2013) approach on different reasons that can motivate individuals, institutions, or states to conclude certain economic decisions. The republic of Benin is used as a case study to theoretically and empirically test how these neoliberal ideas can be applied in real-life situations. We have used a mixed research methodology to collect data and investigated the political and economic reasons that would motivate the Republic of Benin to participate in the AfCFTA. As of January 1, 2021, the agreement is expected to come into force, out of the 54 signatory states over $62 \%$ have already ratified the agreement. The AfCFTA has the potential to grow the intra African trade by $53 \%$. It is also an excellent tool of African integration. After taking into consideration all these variables and considering the fact that Benin has signed the agreement, this paper argued that it will eventually ratify it since the potential benefits outweigh the costs.
\end{abstract}

Key words: The African Continental Free Trade Area, the republic of Benin, Economic Community of West African States, West African Economic and Monetary Union, International Trade.

\section{INTRODUCTION}

$\mathrm{F}$ ree trade Areas are specific geographies or regions where countries mutually agree to eliminate tariffs to boost trade and integration among themselves. The idea of free agreements originated from the classical economic liberalism of $18^{\text {th }}$ and $19^{\text {th }}$ century (Eltis, 2000) and has been reinforced by the $20^{\text {th }}$ century neoliberal free trade theory (Helleiner,
2002). The free trade theory seeks to achieve three main objectives: the elimination of trade barriers, make participating nations more efficient through specialization and to boost economic growth of participating nations. During trade negotiations participating nations, especially small economies carefully evaluate the strengths and weaknesses of the neoliberal free trade theory. Some of the concerns of the small economies such as the Republic of Benin are related to local or infant industries. They are not strong enough to compete with big industries if trade is liberalized. Another problem with trade liberalization is revenue loses for the government as tariffs will be eliminated. Furthermore, it will be difficult for participating nations to individually negotiate trade deals if they are in a trade union. These are some the weaknesses of the neoliberal free trade theory. The Republic of Benin is trying to carefully study how these weaknesses of the neoliberal free trade theory will impact its economy.

The African Continental Free Trade Area (AfCFTA) is a free trade agreement. It was signed on March 21, 2018, in Kigali. It is an ambitious mega project of the African Union (AU). It combines a population of approximately 1.2 billion people and a GPD of 3.4 trillion (World Bank, 2020). The Lagos Plan of Action of 1980 (Kuhlmann \& Agutu, 2020), the Abuja Treaty, the Siirte Declaration, and many rounds of negotiations, have already set up the building blocks on which the AfCFTA is going to operate.

Phase One negotiations of the agreement have been concluded. It incorporates the protocol on trade in goods; the protocol on trade in services; and the protocol on dispute settlement. According to many analysts, the agreement in its comprehensive evaluation is promising as the positive impacts outweighs the negatives. Along with the AU passport and the African single airspace, the AfCFTA is one of the most ambitious projects conceived by African technocrats and scholars. It is expected to accelerate African integration. And a sure pathway to achieving the African Union Agenda 2063. COVID-19 might have disrupted the implementation process as scheduled before the crisis but it does not seem to stop African countries to carry on this ambitious project. The negotiations have been moved to online platforms (Atcho \& Tankou, 2020). And on August 17, 2020, the secretariat of the AfCFTA was inaugurated by the Secretary General, Wamkele Mene in Accra, Ghana. The agreement is expected to come 
into force on January $1^{\text {st }}, 2021$. The AfCFTA has three main objectives to achieve: to increase intra-African trade; create wealth and prosperity for the African people; and to have a united and common trade policy at the global level. The current Intra-African trade is about $12 \%$. It is one of the lowest in the world compared to the European Union at $61 \%$ and Asia-Pacific Economic Cooperation at 67\% (Pasara, 2019 p.2). Regional Economic Communities (RECs) also have an important role to play in the acceleration and the implementation of the agreement. Their regional economic integration experience and technical inputs can help the African commission to smoothly harmonize the three protocols with their regional rules and regulations.

The Republic of Benin, one of the 45 small economies parties to the agreement, is yet to ratify it as of December $31^{\text {st }} 2020$ when this study is completed. Initially, the country refrained from even signing the agreement let alone ratifying it. It was not until July $7^{\text {th }}, 2019$ during the Niamey summit that it signed the agreement along with Nigeria, the biggest economy of the continent with $\$ 448.12$ billion worth of GDP World Bank (2019). But what can explain this shifting position of the Republic of Benin? Many attempts have been made to explain why Nigeria did not want to initially sign the agreement let alone ratifying it. However, as far as the Republic Benin is concerned little or no attempt was made to explain why the country did want to sign or ratify the agreement. The motivation behind this study is to try to find out why the Republic of Benin is skeptical about ratifying the agreement, and why it should ratify it. This study is conducted between July $7^{\text {th }}$, 2019 when the Republic of Benin signed the agreement without ratifying it to the New Year's Eve when the agreement is expected to into force.

\section{INCENTIVES}

An incentive is simply defined as a thing that motivates or encourages someone to do something (Cambridge Dictionary 2020). Political and economic incentives are intertwined. Some of the incentives for economic cooperation are trade, transfer of technology, and market power. Incentives for political cooperation, on the other hand, would be to harmonize political interests and to create strong economic institutions. The economic incentives will be discussed in the section on trade. The government of the Republic of Benin before ratifying the African Continental Free Trade Area (Since it has already signed it) is going to examine all possible advantages and disadvantages. This is because the agreement creates legal rights and obligations vis-a-vis the country.

Harmonization of political interests can encourage the Republic of Benin to ratify the agreement. The political weight of the country is not very important relative to other African countries. The population is about 12 million people, ranked $29^{\text {th }}$ out of 58 countries and territories in Africa. Its territory ranked $37^{\text {th }}$ with $112760 \mathrm{~km} 2$. The Country's nominal GDP is about $\$ 11.386$ billion (UN Department of Economic and Social Affairs, 2019). The Republic of Benin with a relatively small size in GPD, population, and territory cannot get as many concessions when negotiating trade deals individually as when negotiating in a group. The same analysis is true for the other 29 small economies on the continent. The Republic of Benin is better off when it negotiates trade deals in a group together with its other African counterparts that are party to the AfCFTA. Together with the Republic of Benin, the countries party to the agreement will have a combined GDP of \$ 3.4 trillion, a population of 1.2 billion people, and a vast territory of 30.3 million $\mathrm{km} 2$. Negotiating trade deals with such size of GDP and population would likely give the African countries a competitive advantage against its trading partners. It is logical to assert that, from the political incentive standpoint, the Republic of Benin will try to harmonize its interest with the interest of other African states to make it more appealing during trade negotiations.

The second incentive is about the reputation of the country. If the country refuses to sign up for the agreement, how is it going to affect its reputation and that of the government in charge of political decisions? According to Decree $N^{\circ} 2017$ 586 of December $13^{\text {th }}, 2017$ about the attributions, organization, and the functioning of Benin's Ministry of Foreign Affairs, one of the nine core objectives of the ministry is "to ensure the promotion of regional and African integration". The AfCFTA epitomizes this vision. Refusing to ratify the agreement will be contradictory to the vision and the aspirations of the founders of the Republic of Benin. Treaty ratification in the Republic of Benin needs approval from the National Assembly of Benin. Like most states in the world, international law is superior than internal law in the Republic of Benin. This is explicitly stated in article 147 of its constitution. The AfCFTA core objectives are in line with Benin's core objectives regarding African integration. Against this backdrop, it can be contended that the Republic of Benin will eventually join the club because it also seeks to foster African integration both from the political and economic standpoints.

\section{THE POWER OF TRADE}

Countries participate in international trade for fundamentally three reasons (differences in technology, natural resources, and climate) all of which contribute to one thing, which is a gain from trade. In international trade, each participant wants to bet on its strengths and advantages to make trade possible and try to draw the maximum benefits.

Production of scale is the second reason why countries participate in international trade. It is derived from the theory of specialization and the division of labor (Smith, 1776). A country can produce, at a large scale what it is efficient at, through specialization.

The third reason why countries participate in International Trade is to form trade unions to strengthen economic ties and a uniform (common) trade policy both internally and externally. In other words, to aggregate their economic 
interest. In the real world, international trade is the reflection of all of these motives.

The Republic of Benin has a favorable climate, abundant natural resources to produce certain agricultural products such as cotton, cashew, bananas, pineapple, shea nuts, etc. But the technology needed to efficiently produce and process these products is not as developed as it should be. So, how can signing the AfCFTA would participate in improving the technological capacity of the country?

Technological capacity is to be understood from three different angles: agricultural mechanization, modern infrastructure to facilitate commerce, and a need for free movement of skilled labor to share and transfer technology and know-how. Agricultural Mechanization in Benin and most of Sub-Saharan Africa is estimated to be about 5\% while $80 \%$ of lands are cultivated by hand and $15 \%$ by animals (Daum \& Birner, 2020 p.2). The AfCFTA can accelerate the agricultural mechanization process. When agriculture is liberalized it will accelerate private investment in the sector.

However, agricultural liberalization is not an easy job. For the record, one of the main challenges of the Uruguay and Doha Rounds of the World Trade Organization (WTO) was agricultural liberalization. Developing countries are very sensitive to agricultural liberalization. The AfCFTA can face similar challenges. Because, economic integration sometimes favors stronger economies, with competitive enterprises that tend to dominate regional markets, consequently, outperforming infant enterprises in supplying the regional markets. Access to a larger continental market of 1.2 billion people tariff-free will give incentive for more investment for production of scale of agricultural products in Benin. The unemployment rate will eventually drop.

But, it can take many years before domestic industries can adequately compete with other companies on the continent. Currently, the top 4 trading partners of Benin are Bangladesh, India, Vietnam, and China. They represent about $62.2 \%$ of Benin over whole export (HOUNSA \& COUTHON, $2020 \mathrm{p}$. 5). Only $1 / 5$ of Benin exports is for the African market. Considering that, the adjustment cost for Benin for joining the AfCFTA may not be very significant because most of its trading partners are outside the continent. Revenue losses from the government side will be about only $1 / 5$ of the total revenue collected from tariffs. Alternative tax collection can be developed (such as income tax, tax on online shopping, or tax on mobile phone users) to compensate the losses the country may incur for being a member of the AfCFTA. Under the AfCFTA framework, the Republic of Benin can easily increase output and productivity level to create more wealth, export additional products to the African market with fewer transportation costs and customs duties, because the AfCFTA is expected to increase intra-African trade by $50 \%$. Hence, Benin export inside Africa is expected to also increase by $50 \%$. However, an in-depth comparative analysis is needed to evaluate how the Republic Benin will be better off if it decides to export more in the African market than the other parts of the world.

The other angle is related to modern infrastructure to facilitate trade. One important thing that can accelerate private investment in infrastructure for commerce is trade opportunity. When a ready market is available for production, investment would naturally flow others variable being constant.

As far as the movement of skilled labor is concerned the article 3(c) of the agreement establishing the AfCFTA stipulates that "to contribute to the movement of capital and natural persons and facilitate investments building on the initiatives and developments in the State Parties and RECs;" When people can freely move, skilled labor tend to move where they are more efficient and most needed. If the Republic of Benin is a party to the AfCFTA its needs for skilled labor can be filled progressively.

The production of scale is the second reason why countries participate in International Trade.

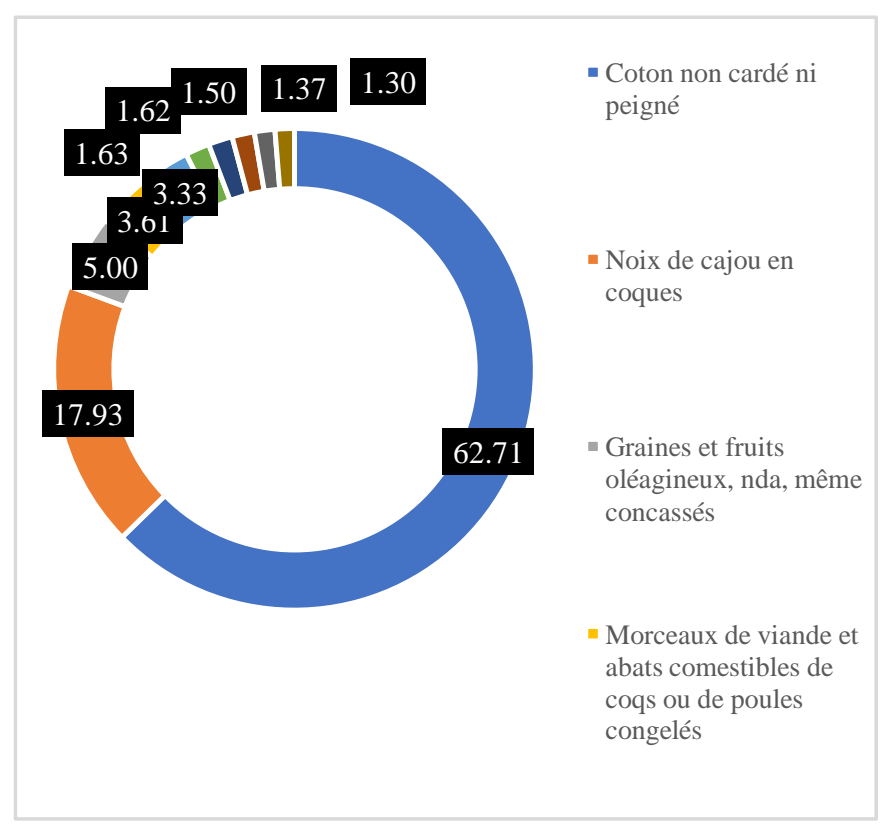

Source: INSAE, 2019

From the above Pie chart, we can see that Cotton and Cashew nuts combined make about $80 \%$ of Benin export. Thus, the Republic of Benin is efficient in producing Cotton and Cashew nuts. An increase in productivity level through the transfer of new technology and employment generation are some of the advantages of joining the AfCFTA. But it is very important to note that signing and ratifying the AfCFTA comes at a cost. The government will eventually have limited power to negotiate or formulate trade policies that are inconsistent with the agreement establishing the AfCFTA. The country is already a member of two important regional and sub-regional organizations: The Economic Community of West African States (ECOWAS) and the West African 
Economic and Monetary Union (WAEMU). These two economic organizations were established by the Lagos treaty in 1975, and the treaty of Dakar in 1994 respectively. These treaties have already put restrictions on how the government can carry out trade policy. The AfCFTA will even put an extra layer on the already existing restrictions imposed by the two regional economic organizations. Nevertheless, article 28 of the agreement establishing the AfCFTA allows state parties to the agreement to take some restrictive measures in case of difficulties with their balance of payment. Also, further liberalization of the domestic market can impede the growing pace of the domestic infant industries of the Republic of Benin. That's why article 24 of the agreement establishing the AfCFTA related to "Infant Industries" states that "states party to the agreement may impose measures to protect domestic infant industries with strategic importance provided that reasonable measures are taken to overcome the difficulties related to such industries". It is a way of protecting Benin infant industries, especially from Nigeria products with a competitive advantage. Economic integration tends to favor economies that are stronger relative to others, with more competitive enterprises that tend to dominate regional markets, thereby, outperforming weaker enterprises in supplying regional markets. From an international trade standpoint, the Republic of Benin has more to gain than it would lose. Favorable climate and natural resources already exist in the country, the AfCFTA has the potential to ameliorate the technology of the country, to accelerate production of scale, and to create a platform where Benin's interest can be reinforced and protected.

\section{THE INSTITUTIONAL FRAMEWORK}

The institutional framework plays an important role in making sure that a legal and political system within which the AfCFTA is going to operate is created. An environment where rights and obligations are created to discipline the participants. For that matter, the agreement establishing the AfCFTA is the epicenter around which the institutional foundation of the AfCFTA is based. Four important institutions are mainly responsible for carrying out the activities of the AfCFTA: The Assembly, the Council of Ministers, the Committee of Senior Trade Officials, and the Secretariat. The main role of the Assembly is to adopt interpretations of the agreement; it is also the highest organ of the AfCFTA. The council of ministers brings together the ministers of trade or designated officials to discuss trade-related issues and make a recommendation to the Assembly. The Committee of Senior Trade Officials' role is to implement decisions from the Council of Ministers. Finally, there is also a Secretariat whose main role is to monitor compliance and the effective implementation of the agreement by different stakeholders. Countries party to the agreement want to see their rights and interests protected within the framework AfCFTA agreement.

It is difficult to appreciate the pertinence of the newly established institutions of the agreement. However, considering the number of years devoted to draft the agreement, and the different rounds of negotiations held by all stakeholders, it is safe to assert that the foundation needed to keep those institutions strong, credible, and durable is set. As far as the Republic of Benin is concerned, it wants to see some core principles to be respected and promoted by both the agreement creating the AfCFTA and each country party to the agreement. These core principles are stability, sustainability, and ultimately mutual respect of sovereignty.

Having said that, does the Republic of Benin think that the necessary institutional framework is guaranteed and well developed enough to ensure that the core principles underlined in the agreement are fair enough to motivate the country to sign up for the agreement? To answer this question, one must certainly have a look at the official statements of the government and the parliament of the Republic of Benin. As this study is finalized, the republic of Benin government is still under many consultations with members of the National Assembly for the ratification of the AfCFTA. From November $7^{\text {th }}$ to November $10^{\text {th }}, 2020$, the Parliament of ECOWAS was in Cotonou to discuss the AfCFTA and other issues as well. At the end of the three-day visit of the MPs of ECOWAS, the vice president of Benin's National Assembly Ms. Mariama Talata Zimé gave her impressions about the meeting but has not explicitly stated when or how the Republic of Benin is going to ratify the agreement (AGOSSOU,2020). Nigeria has already ratified the agreement on November $12^{\text {th }}, 2020$ ahead of the AU December 5th, 2020 deadline (Ukpe, 2020). But Benin is yet to ratify it. This clear indication that in the National Assembly of the Republic of Benin ratification procedure is not as smooth as in other states. But the necessary institutional prerequisites already exist to encourage the Republic of Benin to follow on the path of its peers that have already signed the agreement.

\section{CONCLUSION}

The African Continental Free Trade Area is certainly an ambitious initiative. It is a sure path to integrating the African continent socially, politically and economically. 20 countries including the Republic of Benin are yet to ratify the agreement as this research is finalized on December $31^{\text {st }} 2020$. This paper analyzed three major ideas that motivate countries to operate certain economic decisions: Incentive, Power of Trade, and the Institutional Framework. Qualitative and quantitative evidence showed that the Republic of Benin will eventually sign the agreement because the country stands to gain more than it would lose by ratifying the agreement. This paper has demonstrated that by looking into the Benin's economic and political position in Africa which indicates that the country is better off if it ratifies the agreement. We found out that the revenue loses will be about only $1 / 5$ of the government total revenue which can compensated through alternative tax revenues collection. Another important finding is over $50 \%$ of African countries have already ratify the agreement. The Republic of Benin does not want to be an outsider in the African countries club. Nevertheless, some 
minor concerns remained especially about the fate of the infant industries in country if trade is liberalized. However, whether or not the AfCFTA be considered as a substitute or a supplement to economic multilateralism is another issue altogether.

\section{REFERENCES}

[1] Cowen, T., \& Tabarrok, A. (2015). Modern principles of economics. Macmillan International Higher Education.

[2] AU Member Countries Create History by massively signing the AfCFTA Agreement in Kigali. (2020, November 01). Retrieved November $\quad 01, \quad 2020, \quad$ from https://au.int/en/pressreleases/20180321/au-member-countriescreate-history-massively-signing-afcfta-agreement-kigali

[3] Kuhlmann, K., \& Agutu, A. L. (2020). The African Continental Free Trade Area: Toward a New Legal Model for Trade and Development. SSRN Electronic Journal. doi:10.2139/ssrn.3599438

[4] Atcho, P., \& Tankou, E. (2020, August 14). In Wake of COVID19, African Union to Keep AfCFTA on Track with Digital Technology. Retrieved November 01, 2020, from https://au.int/en/pressreleases/20200814/covid-19-african-unionkeep-afcfta-track-digital-technology

[5] Pasara, M. T. (2019). An overview of the obstacles to the African economic integration process in view of the African continental free trade area. Africa Review,12(1), 1-17. doi:10.1080/09744053.2019.1685336

[6] GDP (current US\$) - Nigeria. (n.d.). Retrieved November 03, 2020, from https://data.worldbank.org/indicator/NY.GDP.MKTP.CD?locations $=\mathrm{NG}$

[7] Incentive [Def. 1]. (n.d.). In Cambridge Dictionionary(2020 ed.).

[8] World Population Prospects - Population Division. (2019, August 28). Retrieved November 15, 2020, from https://population.un.org/wpp/
[9] Daum, T., \& Birner, R. (2020, June 20). Agricultural mechanization in Africa: Myths, realities and an emerging research agenda. Retrieved November 24, 2020, from https://www.sciencedirect.com/science/article/pii/S2211912420300 $47 \mathrm{X}$

[10] Benin and the IMF. (n.d.). Retrieved November 25, 2020, from https://www.imf.org/en/Countries/BEN

[11] HOUNSA, M., \& COUTHON, E. (2020, March). Grands traits Commerce Extérieur du Bénin[Docx]. Cotonou, Bénin: Institut National de la Statistique et de l'Analyse Economique.

[12] Smith, A. (1776, January 01). An inquiry into the nature and causes of the wealth of nations: Volume One. Retrieved November 27, 2020, from https://era.ed.ac.uk/handle/1842/1455?show=full

[13] AGOSSOU, J. (2020, November 01). Renforcement de capacités sur la Zone de libre-échange continentale africaine : Les députés béninois accueillent leurs homologues de la CEDEAO à Cotonou. Retrieved December 01, 2020, from https://visages-dubenin.com/renforcement-de-capacites-sur-la-zone-de-libreechange-continentale-africaine-les-deputes-beninois-accueillentleurs-homologues-de-la-cedeao-a-cotonou/

[14] Ukpe, W. (2020, December 01). Ratification, border opening and stakeholders' views, as AfCFTA is set to commence January 2021. Retrieved December 01, 2020, from https://nairametrics.com/2020/12/01/ratification-border-openingand-stakeholders-views-as-afcfta-is-set-to-commence-january2021/

[15] Helleiner, E. (2002). Economic Nationalism as a Challenge to Economic Liberalism? Lessons from the 19th Century. International Studies Quarterly, 46(3), 307-329. doi: $10.1111 / 1468-2478.00235$

[16] Eltis, W. (2000). The classical theory of economic growth. In The classical theory of economic growth (pp. 310-338). Palgrave Macmillan, London. 